\title{
Roadmap for the adoption of the euro in Hungary: dangers and opportunities
}

Journal of Economic Literature (JEL) code: E42, E58, F33.

\section{Introduction}

In April 2003, the EU Accession Agreement was officially signed for the Czech Republic, Estonia, Cyprus, Hungary, Latvia, Lithuania, Malta, Poland, Slovenia and the Slovak Republic. These countries are destined to become EU members in May 2004. As part of the "acquis communautaire", participation in the new version of the exchange rate mechanism (ERM II), and subsequently in the European Monetary Union (EMU) is obligatory for all new EU members (no opt-out clause is available). Therefore, the question today for the accession countries is no longer whether or not to enter the eurozone but rather the time horizon when the entry should happen.

More specifically, as a condition for EMU membership, a country must be prepared to adopt the euro as the single currency and be able to meet the obligations arising from the Stability and Growth Pact. The formal condition for a country's preparedness to adopt the single currency is the fulfilment of a set of nominal convergence criteria, the so-called Maastricht criteria.

Although the Central-Eastern European countries (CEECs) are following strikingly different patterns of economic policy (from currency board arrangements to managed floating coupled with inflation targeting monetary strategies ${ }^{2}$ ) the endpoint is the same: by around 2010 all of them wish to join the monetary union, fully harvesting the possible gains of the single market. So far the most ambitious time-schedule was announced by the Hungarian government: in July 2003 it declared the intention to introduce the euro by 1 January 2008 (Government of the Republic of Hungary [2003] pp. 11-20).

The paper is organized as follows. First, I will outline the legal regulations concerning the Economic and Monetary Union, and evaluate the preparedness of the whole region in general. Then in Section 3, a detailed picture about Hungarian macroeconomic tendencies will be offered, in light of the above mentioned criteria. Section 4 will discuss the feasibility of the 2008 target date, and set out the arguments regarding the optimal timing of eurozone entry. Section 5 will conclude.

\footnotetext{
1 Paper presented at the conference on "Institutional and Policy Diversity - Its role in Economic Development", Debrecen, Hungary, 3-5, November 2003. László Jankovics is an assistant lecturer at University of Debrecen, Faculty of Economics and Business Administration, Department of Economics e-mail: laszlo.jankovics@econ.unideb.hu

${ }^{2}$ See Begg et al.[2001] and Buiter - Grafe [2001] for more details about the differing paths of the CEECs during the run-up to the euro.
} 


\section{Legal and economic aspects of the eastward expansion of the eurozone}

The Maastricht Treaty (Treaty on European Union, TEU) lays down a very specific procedure for joining, which demands meeting accurate targets over specific time periods ('reporting periods'). Once a country has become the member of the EU, it can also join the modified European exchange rate mechanism, the ERM II. The first four criteria (i.e. public debt, current fiscal deficit, long-term interest rates and inflation) must be satisfied on data from the year prior to the evaluation date. The reporting period for the fifth main criteria ERM II membership without devaluation - is two years according to the TEU, hence the evaluation in this case cannot be made until a two-year track record exists ${ }^{3}$.

Furthermore, the Accession Treaties clearly stipulates the legal requirements of joining the European institutions. It is fair to say that participation in the Economic and Monetary Union and consequently meeting the Maastricht criteria is not an option but an obligation for the accession states. „Each of the new Member States shall participate in Economic and Monetary Union from the date of accession as a Member State with a derogation within the meaning of Article 22 of the EC Treaty." (Ministry of Foreign Affairs [2003])

As I argued, in a legal sense the new member states will have to proceed towards the eurozone. It is important to bear in mind however, that there is a strong camp in the EU which oppose a quick expansion of the monetary union (the most famous spokesperson of this group is Ernst Welteke, incumbent president of the Bundesbank). Besides this, some of the applicants also want to slow down the process, postponing the abandonment of monetary sovereignty past 2010 (Mladek [2003]).

It is certainly worth analyzing whether the transition countries are matured economically at all for the single currency. In the academic literature almost all the evaluations are based on the famous concept of "Optimum Currency Area" $(\mathrm{OCA})^{4}$. If we look at the essential considerations of the theory, we must come to the conclusion that the CEECs are at least as suitable for monetary unification as were the present eurozone countries at their time of joining (see for example Gros [2000], Kopits [2002] and Csajbók-Csermely [2002] pp. 15-82.). The similarity to the Western European economic structures, the diversified sectoral structure in the region, the existence of equalising mechanisms to accommodate potential asymmetric shocks -all measures on which the newcomers do not score significantly worse than the present members. There are also aspects from which the picture is even better: for example the accession countries are more integrated (more embedded) into the single market in terms of international trade volumes than some of the old EU states. Table 1 shows economic interdependences ranking together the present and new Member States.

\footnotetext{
${ }^{3}$ It is interesting to note however, that in May 1998 Italy's and Finland's formal ineligibility were overlooked by the European Commission and the European Monetary Institute (the precursor of the ECB), disregarding the fact that Italy had been in the ERM for only 15 months before the evaluation and Finland for only 16 months.

${ }^{4}$ See the seminal papers of Mundell [1961] and McKinnon [1963] for details of the classical theory, and Horvath [2003] for a contemporary evaluation.
} 
Table 1. Intensity of trade relations in Europe in 1999

\begin{tabular}{|l|c|c|}
\hline & EMU trade/GDP & EMU trade/Total trade \\
\hline Belgium & 81,4 & 56,8 \\
\hline Hungary & 73,2 & 68,7 \\
\hline Czech Republic & 65,1 & 61,7 \\
\hline Estonia & 62,0 & 45,1 \\
\hline Slovenia & 61,8 & 67,1 \\
\hline Slovakia & 58,9 & 56,8 \\
\hline Netherlands & 48,8 & 47,9 \\
\hline Ireland & 44,2 & 33,2 \\
\hline Bulgaria & 39,3 & 54,2 \\
\hline Portugal & 38,5 & 67,1 \\
\hline Austria & 37,6 & 63,2 \\
\hline Romania & 34,7 & 66,4 \\
\hline Latvia & 30,9 & 46,8 \\
\hline Poland & 27,6 & 58,5 \\
\hline Lithuania & 26,5 & 36,0 \\
\hline Spain & 25,5 & 58,3 \\
\hline France & 21,7 & 51,9 \\
\hline Germany & 20,8 & 43,8 \\
\hline Finland & 20,7 & 34,0 \\
\hline Italy & 19,5 & 49,3 \\
\hline Greece & 17,4 & 53,4 \\
\hline & & \\
\hline & & \\
\hline
\end{tabular}

\section{Source: Eurostat}

From the data it is striking that the transition countries are far more concentrated toward the European Union. Consequently the single currency could eliminate the exchange rate risk for a larger share of foreign trade. If we look at other economic variables, over the last couple of years in the region the achievements in some aspects are undisputed. Figure 1 and Figure 2 present some figures on recent macroeconomic performance. 
Figure 1. Average CPI in selected transition economies

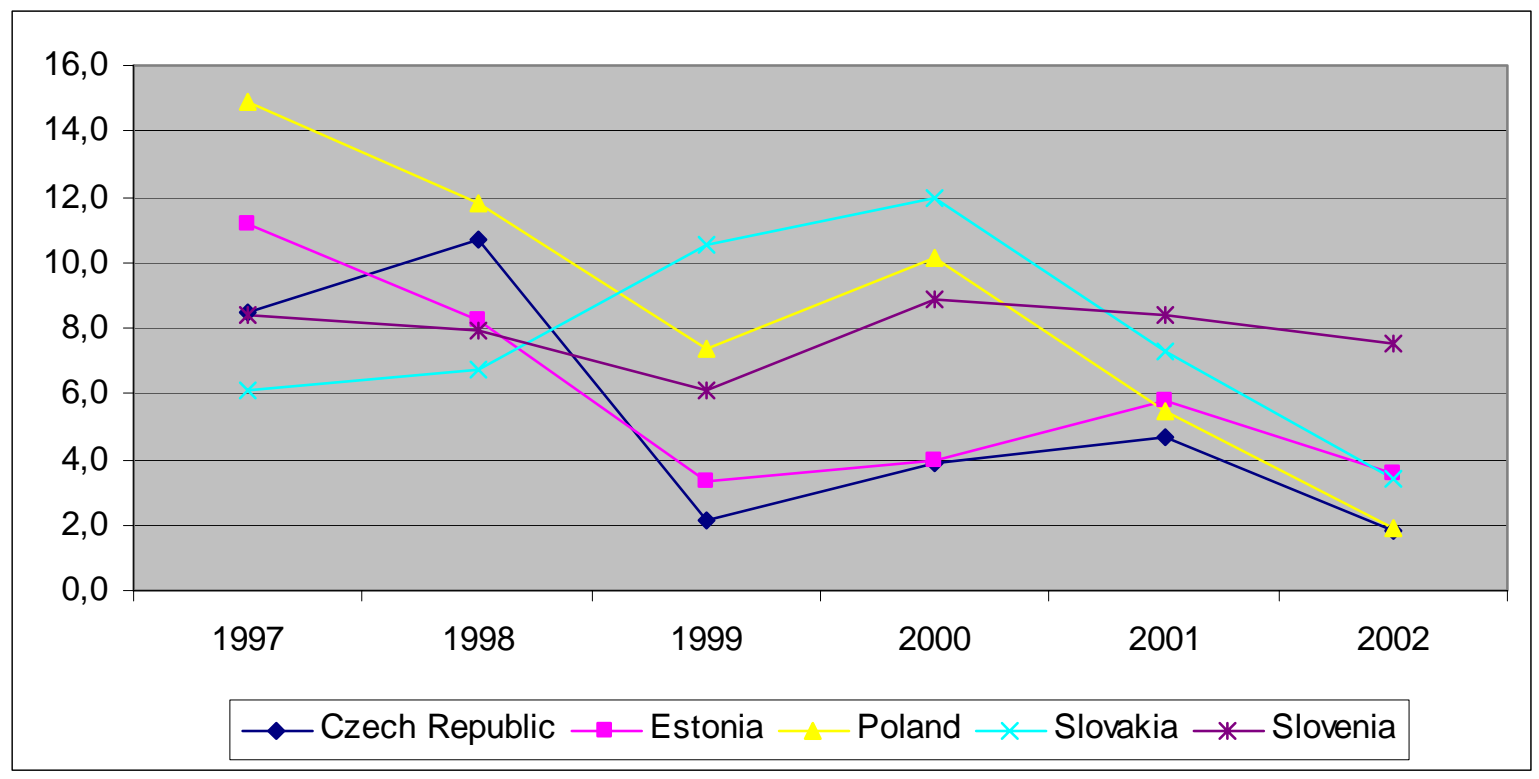

Source: Kopint-Datorg [2003]pp. 28.

Figure 2. Real GDP in selected transition economies

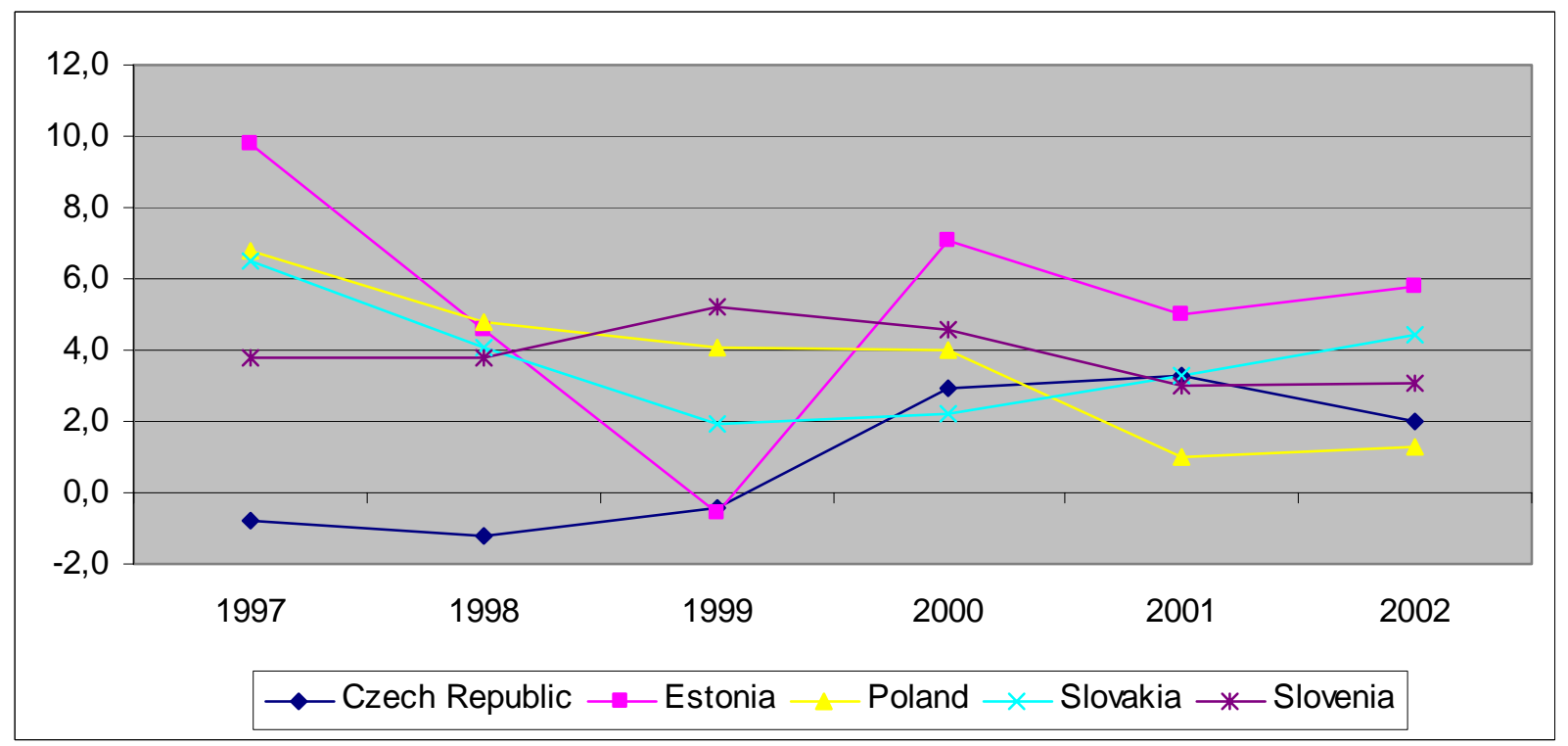

Source: Kopint-Datorg [2003]pp. 27.

It is noticeable from the comparison in Figure 1 that the CEECs achieved low levels of price increases, and inflation remained in moderate levels despite the variety of exogenous shocks during the given period (Asian and Russian financial crises; the collapse of the stock exchanges and the myth of the "new economy"; substantial increases in world commodity prices). It is also evident from Figure 2 that transition countries have remained resilient to the sluggishness of the global economy. Growth in the region after 2000 certainly slowed down, but still outpaces the global economies, not to mention the EU average. The consolidation and stabilization of the accession states' economies lays down the foundation for continuing real convergence in economic development and the adoption of the single currency over the medium term. 


\section{The Hungarian macroeconomic picture in the light of the euro}

After Hungary's EU-accession scheduled to May 2004, entry into the Economic and Monetary Union will be the next major step in the country's European integration. EMU-entry will eventually entail giving up the national currency and introducing the euro as the domestic means of payment.

As mentioned above, the Hungarian government was among the first in the region to declare an ambitious target date to adopt the single currency. Certainly a well-defined macroeconomic path is attached to this plan, since fulfilling the Maastricht criteria would require disciplined, or sometimes harsh economic policies. Table 2 gives us some insight about the recent trends of the Hungarian economy.

Table 2. Hungarian macroeconomic indicators 1996-2002 (percentage points)

\begin{tabular}{|lccccccc|}
\hline & $\mathbf{1 9 9 6}$ & $\mathbf{1 9 9 7}$ & $\mathbf{1 9 9 8}$ & $\mathbf{1 9 9 9}$ & $\mathbf{2 0 0 0}$ & $\mathbf{2 0 0 1}$ & $\mathbf{2 0 0 2}$ \\
\hline GDP & 1,3 & 4,6 & 4,2 & 4,9 & 5,2 & 3,8 & 3,3 \\
\hline Exports & 7,4 & 26,4 & 16,7 & 12,4 & 21 & 8,8 & 3,8 \\
\hline Imports & 5,7 & 24,6 & 22,8 & 13,3 & 19,4 & 6,1 & 6,1 \\
\hline CPI & 23,6 & 18,3 & 14,3 & 10 & 9,8 & 9,2 & 5,3 \\
\hline Unemployment rate & 10,1 & 8,9 & 8 & 7,1 & 6,5 & 5,6 & 5,6 \\
\hline Current Account \% of GDP & $-0,9$ & $-0,6$ & -2 & $-2,3$ & $-3,2$ & -2 & $-2,8$ \\
\hline $\begin{array}{l}\text { Government balance \% of } \\
\text { GDP }\end{array}$ & -3 & $-4,6$ & -9 & $-5,3$ & $-2,6$ & $-4,5$ & $-9,2$ \\
\hline
\end{tabular}

Source: Kopint-Datorg [2003]pp. 53.

The data clearly show that overall economic growth is slowing in Hungary, in reaction to a contraction in corporate investment spending and exhausting export activities. In the short term, it can be argued that recent export performance has been a result of weak growth in the main European trading partners. However, deeply-seated factors can be found in a loss of competitiveness due to several years of unsustainably large real wage increases, steady currency appreciation in real terms, and a declining rate of manufacturing productivity performance. With a tight labour market, relatively high wages and just a few remaining privatization projects, there is little chance that massive foreign direct investment (FDI) flows can counter these factors. During the second half of the $90 \mathrm{~s}$ a healthy capital account dominated by large FDI inflows could finance the current account deficit without increasing the foreign debt of the country ${ }^{5}$. In fact, increasing capital exports by Hungarian large corporations (e.g. MOL, OTP, MATÁV) will undercut any positive impact on external financing, although it might help the income balance of the current account by repatriating profits and dividends later.

As recently as 2001-2002, the inflation criteria was said to be the toughest challenge for Hungary among the Maastricht set. Since then, election politics substantially overwrote all projections, and the last two governments (the Orbán- and the Medgyessy governments) expansionary economic programmes caused budget irrationality, with subsequent spillovers into the current account and fiscal deficit. Although the outstanding 2002 budget deficit was partly a function of consolidation of one-off items, such factors were estimated to account for

\footnotetext{
${ }^{5}$ See Bokros [2000] for patterns of the recent economic boom in Hungary in regional comparison.
} 
4\% of GDP last year. This suggests that the deficit excluding these one-off items would otherwise had been around 5,3-5,5\%, which is still high, but not extraordinary compared with Hungary's regional neighbours. Nevertheless, the markets remained unconvinced by the governments' commitment in balancing the budget over the medium term consistent with the respective Maastricht criteria. Although the government emphasizes the need to pursue an increasingly tight fiscal position, meeting fiscal targets within the political context of a narrow parliamentary majority and with 2006 general election looming on the horizon will be difficult. Furthermore, Kopits - Szekely [2003] emphasized that during the next couple of years additional fiscal costs will emanate from meeting the EU standards and regulations on fields as diverse as environment, institution building, transportation and taxation.

It is important to stress here that the lively debate concerning the mechanisms and the very logic of the Stability and Growth Pact ${ }^{6}$ should not be interpreted as a relaxation of the fiscal criteria. First, it is always different what rules are governing the insiders and the outsiders of the club. Second, there is a palpable pressure on the accession states to undergo the same purgatory, which was set in Maastricht back in 1992.

In the field of monetary and exchange rate policy, the last 12 months was overly intriguing. In the first half of January 2003 strong hot capital inflows (driven by speculation on the forint-band widening) strengthened the national currency which reached the upper limit of the fluctuation band. As a result the National Bank of Hungary (NBH) had to intervene directly and bought up approximately 5 billion euros within two days. Furthermore, the central bank cut its key interest rate in 2 steps from $8.5 \%$ to $6.5 \%$, limited access to two-week depo facility, and widened the interest rate channel from $+/-100 \mathrm{bp}$ to $+/-300 \mathrm{bp}{ }^{7}$.

These responses to the speculation proved to be successful, as the outflow of speculative capital did not jeopardize the stability of the financial system and the band was defended successfully (Barabás [2003]). As a result, the bulk of the speculative money had left the country by late May; however, the forint did not weaken and remained stable during this period. The reason behind this is that central bank was selling previously bought up extra reserves by using silent interventions. This instrument kept the exchange rate stable, somehow artificially, around $245 \mathrm{Ft}$ /euro. At the end of May the NBH decided to withdraw from the foreign exchange market and restore its former practice of influencing exchange rate movements primarily via interest rate changes.

A second issue, which had an impact of further weakening the forint was a policy measure on 4 June 2003. The central bank and the Government jointly depreciated the centre of the intervention band by $2.26 \%$ in order to prevent any excessive appreciation of the currency and to contribute to improving the international competitiveness of Hungarian economy and the Hungarian exporters. The new upper limit was set at 240.01/EUR (the former 234.69), 324.71/EUR (317.52) the lower limit and 282.36/EUR (276.1) the central parity. According to official reasoning, the monetary council evaluated the situation as the agreement provides them still enough room for manoeuvre within the new intervention band and due to several favourable impacts on inflation (such as deflation in Germany, slower than expected growth in Hungary), inflation targets are not in danger at a lower exchange rate. The Central bank was of the opinion that its inflation targets $(4.5 \%$ for year-end 2003 and $3.5 \% \pm 1 \%$ for year-end 2004) can be met with an exchange rate of $250-260 /$ EUR, and 245/EUR is not a must if the government implements its promised immediate fiscal adjustment program of HUF 79 billion.

However, timing and communication of the decision was heavily criticized, since the forint was on a weakening trend already and there was no official comment beforehand.

\footnotetext{
${ }^{6}$ See Benczes [2003] for details.

${ }^{7}$ For a thorough discussion of the instruments of Hungarian monetary policy see NBH [2002] pp. 89-122.
} 
Consequently, the market was not only surprised but very confused. After the band shift was announced the forint weakened drastically and hit 270/EUR. Policy makers had to take immediate actions to calm down markets and the NBH hiked its interest rate to $9.5 \%$ in two steps in June.

According to market analysts and some academics the basic problem of the current monetary regime is a dangerous mix of both exchange rate and inflation targeting (Jonas Mishkin [2003]. This kind of mix makes the country vulnerable and exposed to speculative attacks given the fully open capital account. The practice of the central bank was to declare a certain exchange rate band inside the wider official bands, which was deemed to be compatible with the inflation target. The coexistence of the two targets made the interest rate policy too volatile, triggering aggressive rate cuts and hikes as a reaction to currency market developments.

\section{The debate about the timing of eurozone entry}

In a thorough analysis the research staff of the National Bank of Hungary made the economic case for the "as soon as possible" approach concerning the introduction of the single currency (Csajbók-Csermely [2002]). They estimated significant net gains, assuming that euro area membership might raise the Hungarian GDP by 0.6 to 0.9 percent in terms of a 20 -year term average. Postponing the adoption of the euro consequently would mean sacrificing this additional growth potential. The present government is seemingly convinced by this set of arguments, since the declared 2008 target date is appropriate for this as soon as possible line. The NBH immediately endorsed this schedule. However, there is a recurring debate concerning the optimal timing of the eurozone entry, and, in my opinion, it can be taken for granted that over the next couple of years, this topic will be hotly discussed among economic and political circles.

There are several often-cited counterarguments which aim to postpone the introduction of the euro past 2010. I would like to raise these points, and the argue for the present timetable, although I'm fully aware of the political and economic difficulties to overcome in order to preserve the plan.

First, one can argue that meeting the official target would require artificially quick disinflation and a fiscal straitjacket. Nonetheless, Csaba [2002] pointed out that although the common currency has become effectively a new entry barrier for the CEECs, it should not be seen as an obstacle on the road towards full integration. Rather, it is an incentive for governments to make further fiscal adjustments, and to continue the disinflation process. In this context, the fulfilment of the strict macroeconomic criteria is possible in the coming years if the political commintment is provided. Moreover, as the events of the last economic crises proved, the required solid policies are in the self-interest of the accession countries.

It is important to note here that the recently experienced harsh disagreement inside the EU concerning the application of the Stability and Growth Pact should not be interpreted as a relaxation of the fiscal criteria. Furthermore, a more balanced budget position will be required by the core European institutions.

Second, the postponement of the euro accession would mean that the CEECs could continue their sovereign monetary and exchange rate policies to accommodate exogenous shocks during the catching-up process, or even to react to asymmetric shocks (e.g. devalue the national currency in case of unfavourable demand shifts on the world markets). However, retaining the autonomy of monetary policy and the national currency is very dangerous amid free capital flows. All the accession states fully liberalized the capital account in accordance with their international obligations and EU law harmonization process. 
Besides the standard shocks that all open emerging market countries could face, accession states could face a specific external shock: the so-called convergence play. This refers to large capital inflows stimulated by interest rate expectations ahead of EMU accession. Adopting the euro would mean the complete elimination of the currency risk premium and a sizeable decline on default risk premium. Therefore, investors could reasonably expect a sharp reduction in interest rates on debt (fixed-icome) instruments issued by these countries, that would allow them to reap capital gains. Experiences in the Southern member states confirm the view that foreign investors have an incentive to play on the convergence of interest rates to EMU average. The resulting massive portfolio invesments would appreciate the currency and force the central bank to cut the base rate. However, reducing interest rates could conflict with the disinflation process, because it could stimulate domestic demand and thus contribute to the inflationay pressures in the economy ${ }^{8}$. And more incoherently, the latter could require the national bank to hike the interest rates again, which makes the countries debt market more attractive to financial institutions. This can result in accelerated interest rate and exchange rate volatility, itself quite harmful for other sectors of the economy. These unwanted nominal fluctuations can easily attract speculative money into the country, as seen in the January 2003 crisis in the Hungarian financial markets. In other words, retaining the national money throughout this peroid (mainly as a member country of the ERM II) could expose the country to potentially disruptive capital flows (Neményi [2003], Polgár [2003]).

Third, it is also mentioned that it would be a serious mistake to irreverersibly fix the national currency to the euro at an overvalued parity. It certainly would be a folly, but as Oblath [2003] emphasized recently, this has no connection with the concrete timing of the accession. To set an economically justified rate would depend on the rationality and competence of the Hungarian decision-makers, and partly on the same skills of the European institutions since the final exchange rate are decided jointly. It is possible to set a sustainable rate for 2008, and for 2012 as well.

Csaba [2003] wrapped up the debate succinctly, arguing that the whole discussion might have made sense before the announcement of the target date, but after the publication of the official timetable it would be foolish to create uncertainty around the commitment. There is a very good chance that the adandonment of the 2008 target would lead to a complete loss of trust towards economic policy, and there are ample instructive examples of the possible consequences of such a crisis situation in a globalized world economy.

\section{Conclusions}

After the EU-accession the next major challenge will be preparation and finally the introduction of the single currency for the Central Eastern European countries. So far, Hungary has adopted the most ambitious plan by setting its target date for 2008. In this paper, I analyzed the legal, economic and political factors regarding the preparedness of the country alongside the whole region. After taking the pros and cons of the official "as soon as possible" strategy into consideration, we can conclude that there is no convincing case for postponing eurozone entry. Furthermore, putting off the date indefinitely or ambiguously could result in growing economic uncertainty and dangerous financial instability; in other words, slower convergence in every term to the European average.

Nevertheless, to argue for the early adoption of the single currency doesn't mean to advocate the option of unilateral euroization. There is an influential academic circle in Europe

\footnotetext{
${ }^{8}$ This conflict is even more serious in a country like Hungary pursuing an inflation targeting monetary system.
} 
(Bratkowski - Rostowski [2000], Coricelli [2002], Nuti [2002]) who support this solution. However, if we carefully investigate the political and economic consequences of unilateral euroization, ${ }^{9}$ we see that the presumed benefits would probably not exceed the costs and risks implied by such a step. Given the sharp rejection of euroization by all European institutions, it is not worth adopting the single currency unilaterally, since the related benefits are ambiguous and vague, but the risks and costs are present and substantial.

It is important to emphasize here that there is no precedent so far for missing a publicly announced EMU target date in Europe. It is very likely that Hungary would suffer a serious loss of reputation and credibility were it to become the first who could not make it on schedule. Simply, there is no other reasonable way but to keep the plan, be sufficiently committed and achieve the technically still feasible target. Lack of strong political commitment could unfortunately easily lead to a postponement of the adoption of the single currency. Such potential implications might well be debated, but no doubt would be serious in terms of reputation and economic development.

\footnotetext{
${ }^{9}$ See Backé- Wójcik [2002] and Jankovics [2002] for a detailed analyis of the counterarguments.
} 


\section{References}

BAcké, Peter - WóJCik, CezAry [2002]: Unilateral Euroization: a Suitable Road towards Joining the Euro Area for Central and Eastern European EU Accession Countries? In: Sepp, Urmas - Randveer Martti (eds): Alternative Regimes in Entry to EMU. Bank of Estonia, Talinn

BARABÁs GyUla (ED) [2003]: Coping with the Speculative Attack against the Forint's Band. National Bank of Hungary, Background studies, No. 3. Budapest

BRATKOWSKI, ANDRZEJ - Rostowski, JACEK [2000]: The EU Attitude to Unilateral Euroisation: Misunderstandings, Real Concerns, and Ill-designed Admission Criteria. In Brzeski, Andrzej - Winiecki, Jan (eds): A Liberating Economic Journey: PostCommunist Transition, The Cromwell Press for CRCE

BegG, DAVid - Eichengreen, BARry - HAlPern LÁszló - Von HAgen, JÜRgen Wyplosz, Charles [2001]: Sustainable Regimes of Capital Movements in Accession Countries. Centre for Economic Policy Research, London

Benczes IstVÁn [2003]: A Stabilitási és Növekedési Paktum kritikai értékelése. (Critical Assessment of the Stability and Growth Pact). Európai Tükör, No. 4-5. pp. 59-78.

Bokros Lajos [2000]: Visegrad Twins' Diverging Path to Relative Prosperity. Comparing the Transition Experience of the Czech Republic and Hungary. Paper presented at the Conference of the Czech National Bank, Prague, September 22

Butter, Willem H. - Grafe, Clemens [2001]: Central Banking and the Choice of Currency Regime in Accession Countries, Société Universitaire Européenne de Recherhes Financières (SUERF) Studies, No. 11. Wien

Coricelli, FABRIZIO [2002]: Excange Rate Policy during Transition to the European Monetary Union: The Option of Euroization. Economics of Transition, Vol. 10. No. 2. pp. 405-417.

CSAJBÓK AtTILA-CSERMely ÁgNes (EDS) [2002]: Adopting the Euro in Hungary: Expected Costs, Benefits and Timing. National Bank of Hungary, Occasional Papers 24.

CSABA LÁszló [2002]: Pótlólagos felvételi követelmény-e az euróérettség? (The Euro - a New Entry Barrier?) Külgazdaság, No. 2. (February) pp. 32-46.

CSABA LÁsZLÓ [2003]: A Non-Stability and Anti-Growth Pact for Europe? Paper presented at the conference of „From here and from There: New and Old Members' Perception on EU Enlargement". Groningen, September 25-27.

Government of the Republic of Hungary [2003]: Pre-Accession Economic Programme of Hungary 2003. Budapest

Gros, DANiEL [2000]: How Fit are the Candidates for EMU? The World Economy, Vol. 23. No. 10. pp. 1367-1378. 
Horvath, Julius [2003]: Optimal Currency Area Theory: A Selective Review. BOFIT Discussion Papers, No. 15.

JANKovics LÁszLó [2002]: The Bumpy Road to EMU - Similarities and Discrepancies in the Accession Countries. Paper presented at the ICEG EC International Conference on „Exchange Rate Strategies During EU Enlargement”. Budapest, November 27-30.

JONAS, JiRI - MishKIN, FREDERIC S. [2003]: Inflation Targeting in Transition Countries: Experience and Prospects. NBER Working paper 9667

Kopint DAtorg [2003]: Economic Trends in Transition Economies. Vol. 12. No. 2. Budapest

KopITS GYÖRGY [2002]: Central European EU Accession and Latin American Integration: Mutual Lessons in Macroeconomic Policy Design. Oesterreichische Nationalbank, Working Paper 75.

Kopits GyÖRGY-SzÉKely P. IstVÁn [2003]: Fiscal Policy Challenges of EU Accession for the Baltics and Central Europe. In: Tumpel-Gugerell, Gertrude - Mooslechner, Peter (eds): Structural Challenges for Europe, Edward Elgar (forthcoming)

McKinnon, R. I. [1963]: Optimum Currency Areas. The American Economic Review, Vol. 53. pp. 717-725.

MINISTRY OF FOREIGN AFFAIRS [2003]: Treaty of Accession. Official website (http://www.kulugyminiszterium.hu)

MLADEK, Jan [2003]: Csehország és az euró. (The Czech Republic and the euro.) Európai Szemle, No. 1-2. pp. 79-84.

Mundell, RoBert [1961]: A Theory of Optimum Currency Areas. The American Economic Review, Vol 51.pp. 657-664.

NBH [2002]: Monetary Policy in Hungary. National Bank of Hungary, Budapest

NEMÉNYI JUdiT [2003]: Az euró bevezetésének feltételei Magyarországon. (The conditions of the introduction of the euro in Hungary). Közgazdasági Szemle, No. 6. (June) pp. 479504.

NuTI, D. MARIO [2002]: Costs and benefits of unilateral euroization in central and eastern Europe. Economics of Transition, Vol 10. No. 2. pp. 419-444.

OBlath GÁBor [2003]: Az euró haza bevezetése: Belül biztonságosabb. (Introducing the euro in Hungary: It is Safer Inside) Figyelö, Vol. 47. No. 18. pp. 24-28.

Polgár Éva Katalin [2003]: Az Európai Monetáris Rendszer és az ERM-2. (The European Monetary System and the ERM-2). Közgazdasági Szemle, No. 4. (April) pp. 479-504. 